\section{Biogenic amines content in Fiore Sardo cheese in relation to free amino acids and physicochemical characteristics}

\author{
Gavina Manca, ${ }^{1}$ Antonio Ru, ${ }^{1}$ \\ Giuliana Siddi, ${ }^{2}$ Mocci Anna Maria, ${ }^{2}$ \\ Gavino Murittu, ${ }^{3}$ \\ Pietro Luigi De Santis ${ }^{2}$
}

${ }^{1}$ Department of Economics and

Business, Lab of Commodity Science

Technology and Quality, University of

Sassari; ${ }^{2}$ Department of Veterinary

Science, University of Sassari; ${ }^{3}$ F.lli

Pinna Dairy Industry, Thiesi (SS), Italy

\section{Abstract}

Fiore Sardo is a Protected Designation of Origin (PDO) cheese produced in Sardinia (Italy) from raw sheep's milk, presenting risk factors due to an accumulation of Biogenic Amines (BA). A total of 37 Fiore Sardo cheese samples produced in 19 dairy farms were collected from local retail stores to evaluate BA content and its relationship with free amino acids (FAA) and composition. The following were determined for each sample: $\mathrm{pH}$, water activity, composition (moisture, dry matter, $\mathrm{NaCl}$, protein and fat content). FAA and BA, after extraction, were determined by HPLC-FL. The total BA content in Fiore Sardo PDO cheese samples was $127 \pm 87 \mathrm{mg}$ $100 \mathrm{~g}-^{1}$, ranging between 6 and $366 \mathrm{mg} 100$ g- ${ }^{1}$. Tyramine showed the highest concentration ( $\left.82 \pm 51 \mathrm{mg} 100 \mathrm{~g}^{-1}\right)$, followed by putrescine $\left(21 \pm 26 \mathrm{mg} 100 \mathrm{~g}^{1}\right)$. Moreover, cadaverine, histamine, $\beta$-phenylethylamine and tryptamine were detected at concentrations lower than $10 \mathrm{mg} 100 \mathrm{~g}-^{-1}$. Overall 54\% of the samples analysed exceeded the thresh-

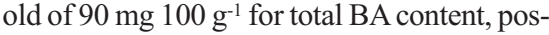
ing a potential risk for consumers. BA, total FAA $\left(2233 \pm 764 \mathrm{mg} 100 \mathrm{~g}^{-1}\right)$ and $\mathrm{pH}$ were positively correlated $(\mathrm{P} \leq 0.01)$ between themselves, whereas BA content was not correlated with $\mathrm{a}_{\mathrm{w}}$, humidity and percentage of $\mathrm{NaCl}$. The hierarchical cluster analysis results, considering 37 samples and 6 variables, detected four different groups. Samples with BA $\geq 200$ mg $100 \mathrm{g-}^{1}$ were distributed in two groups characterized by a higher proteolysis indicator levels (FAA, $\mathrm{pH}$ ) but significantly different for $\mathrm{a}_{\mathrm{w}}$, humidity and $\mathrm{NaCl}$ concentration. The results showed that high levels of BA were detectable in some samples of Fiore Sardo PDO cheese, suggesting that effective technological conditions at production should be adopted.

\section{Introduction}

Biogenic amines (BA) are low-molecular-weight nitrogenous compounds which at low concentrations are essential for natural metabolic and physiological functions in animals, plants and microorganisms (Premont et al., 2001). Nevertheless, BA accumulation occurring in food may have a toxicological effect and pose a foods safety risk, especially for susceptible consumers. Though BAs are usually detoxified by monoamine oxidase (MAO) and diamine oxidase (DAO) in the small intestine, toxic effects may arise through amine oxidase oversaturation due to high concentrations of BA or when detoxifying activity is impaired, due to the use of monoamine oxidase inhibitors (MAOI), alcohol consumption or gastrointestinal disorders (Shalaby, 1996). Tyramine, histamine, tryptamine, $\beta$ phenylethylamine, putrescine, cadaverine, spermidine and spermine are the most common biogenic amines occurring in foods. Fermented foods, meat, beverages, fish and fish products can accumulate high BA concentrations (Ladero et al., 2010; Doeun et al., 2017). Fish and cheese are the foods most commonly associated with amine poisoning (EFSA, 2011). Excessive consumption of foods with a high content of histamine, such as fish and fish products, may result in scombroid poisoning with symptoms similar to allergic reactions, such as dyspnea, headache, hives, diarrhea and hypotension (Taylor, 1986; Ladero et al., 2010). Cheese may contain potentially harmful levels of BA, especially tyramine, a vasoactive amine responsible for the socalled "cheese reaction", with symptoms such as a rise in blood pressure, severe headaches, a hypertensive crisis and heart failure (Smith, 1981; Ladero et al., 2010). In addition, polyamines react with nitrite to form carcinogenic nitrosamines (Kim et al., 2009). The formation of biogenic amines can occur in cheese as a result of bacterial decarboxylation of the corresponding amino acid precursors resulting from the proteolysis process, through substrate-specific decarboxylase enzymes or by deamination and transamination of aldehydes and ketones (Ten Brink et al., 1990; Linares et al., 2012). In cheese, decarboxylase-producing strains could be provided by raw milk, some starter cultures or microbial contamination. Proteolysis, with the consequent release of free amino acid precursors of BA, is affected by rennet and enzyme activity or microbial fermentation during cheese production and ripening. The BA accumulation rate and concentration in cheese is then influenced by the following factors: raw milk hygiene; processing con-
Correspondence: Gavina Manca, Department of Economics and Business, Lab of Commodity Science Technology and Quality, University of Sassari, Via Muroni 25, 07100 Sassari.

Tel: +39.079229579

E-mail: gmanca@uniss.it

Key words: Fiore Sardo Cheese, Raw sheep milk, Biogenic Amines, aw, $\mathrm{pH}, \mathrm{NaCl}$.

Contributions: The authors contributed equally.

Conflict of interest: The authors declare no potential conflict of interests.

Funding: University of Sassari Research Grant 2019-20.

Availability of data and materials: The data that support the findings of this study are available from the corresponding author upon reasonable request.

Ethics approval and consent to participate: This research was conducted in accordance with all relevant guidelines and procedures.

Consent for publication: The manuscript does not contain any individual person's data in any form.

Received for publication: 30 July 2019. Revision received: 7 November 2019.

Accepted for publication: 21 November 2019.

This work is licensed under a Creative Commons Attribution-NonCommercial 4.0 International License (CC BY-NC 4.0).

(C) Copyright: the Author(s), 2020

Licensee PAGEPress, Italy

Italian Journal of Food Safety 2020; 9:8457

doi:10.4081/ijfs.2020.8457

ditions, like milk heat treatment, starter cultures and enzymes, ripening temperature and duration; intrinsic $\left(\mathrm{a}_{\mathrm{w}}, \mathrm{pH}, \mathrm{NaCl} \%\right)$ and extrinsic factors (oxygen concentration, relative humidity) of the product (Silla Santos, 1996; Santos et al., 2003; Linares et al., 2012; Loizzo et al., 2013; Gardini et al., 2016; Doeun et al., 2017).

The presence of BA could be a risk factor for artisanal cheeses (Martuscelli et al., 2005; Mascaro et al., 2010; Schirone et al., 2011; Schirone et al., 2012; Loizzo et al., 2013; Manca et al., 2015). The artisanal Fiore Sardo cheese is a Protected Designation of Origin (PDO) cheese, produced in Sardinia (Italy), in which the use of raw sheep's milk, the intensive fermentation activity carried out by natural autochthonous microorganisms (Mannu et al., 2000; Pisano et al., 2006; Pisano et al., 2007), ripening duration ( $>3.5$ months, 
often even more) and storage temperature, can be identified as risk factors for the formation and accumulation of BA. Therefore, the aim of this research is to assess BA content in Fiore Sardo cheese and evaluate the relationship between the BA content and product parameters such as proteolysis level, $\mathrm{pH}, \mathrm{NaCl}$ concentration, water activity and relative humidity.

\section{Materials and Methods}

\section{Cheese making technology}

Fiore Sardo PDO cheese, as recorded in Regulation (EC) No 1263/96, is manufactured from raw ewe's milk obtained from one or two milkings (evening and morning milking). The cheesemaking process follows traditional technological procedures, and fermentation is carried out solely by the indigenous microbial flora present in the milk or by the addition of natural autochthonous microorganisms by starter culture. The milk is coagulated by adding lamb's milk or kid rennet at $34-36^{\circ} \mathrm{C}$ (during spring or wintertime, respectively). The curd is cut for about three minutes until a millet-seed size is reached. The grains are left to rest for five minutes in the bottom of the vat and the curd, after extraction from the whey, is moulded to obtain the typical wheel, whereby a "mule-back" lateral face is obtained by overlapping two truncated conic shapes. Briefly scalding of the crust may be carried out using hot water or "scotta" (the whey obtained after ricotta cheese production), to obtain a smooth, regular surface. A casein disc is placed on the crust to mark the cheese wheel, which is salted by brining for not more than 48 hours. The first ripening step lasts as long as two weeks, at $18-20^{\circ} \mathrm{C}$ in rooms where the cheese wheels are placed on grids, usually subjected to natural smoking, for about two hours/day. The second ripening steps take place at temperatures between $10-15^{\circ} \mathrm{C}$, usually at farmstead level. During the third ripening step the environmental temperature does not exceed $15^{\circ}$ degrees. During ripening the wheels are turned upside down and their surface is treated with olive oil, vinegar and salt. Ripening time is not less than 3.5 months and 6 months, respectively, for the table and grating types.

\section{Samples and analysis procedures}

A total of 37 Fiore Sardo PDO cheese samples were randomly purchased from local retail stores in Sardinia (Italy). With ripening periods ranging between six and twelve months, the samples were produced by 19 local farms during 2017-18 milking.
One to three batch samples were collected per producer.

The cheeses were brought to the laboratory by refrigerated transport, cut into pieces, discarding up to $1.5 \mathrm{~cm}$ from the rind, and grated. The chemical and physicochemical analyses were carried out on the fresh product, as was the extraction of free amino acids and biogenic amines. $\mathrm{pH}$ values were determined by direct reading using a GLP22 pH-meter (Crison instruments, Barcelona, Spain) and $\mathrm{a}_{\mathrm{w}}$ by Aqualab 4TE (Decagon, Pullman, WA, USA). The FOSS FoodScan NIT (FOSS, Eden Prairie, MN, USA) was used to measure moisture, dry matter, $\mathrm{NaCl}$, protein and fat content. To extract FAA and BA, $2 \mathrm{~g}$ of ground cheese were mixed with $1 \mathrm{ml}$ of a solution containing the internal standards ( $\alpha$-Methyl-DLphenylalanine $5 \mathrm{~g} / \mathrm{L}$ and 1,7Diaminoheptane $0.2 \mathrm{~g} / \mathrm{L}$ in HCL $0.1 \mathrm{M}$ ) and $50 \mathrm{ml}$ of a solution of $\mathrm{HCl} 0.1 \mathrm{M}$, containing $0.2 \%$ of $3,3^{\prime}$-Thiodipropionic acid (TDPA). The mixture was homogenised in an ULTRA TURRAX homogeniser (Zipperer, Staufen, Germany) for five minutes. The cheese slurry obtained was centrifuged (ALC PK131R; ALC International S.r.l., Milan, Italy) at $1250 \mathrm{x} g$ (4000 rpm) for 20 $\min$ at $4^{\circ} \mathrm{C}$. The supernatant was recovered and the residue reextracted using $40 \mathrm{ml}$ of $\mathrm{HCl}$ 0.1 M. Then the two acid extracts were combined, and the volume adjusted to 100 $\mathrm{ml}$ with trichloroacetic acid $1 \mathrm{M}$. The extract was derivatised with Dns-Cl following the Eerola method (1993), with some modifications, such as a reduction in the amount of sodium carbonate and small changes in temperature and time. $50 \mu \mathrm{L}$ of sodium carbonate $1 \mathrm{M}$, and $400 \mu \mathrm{L}$ of dansyl chloride solution $(1 \% \mathrm{w} / \mathrm{v}$ in acetone) were added to 250 $\mu \mathrm{L}$ of standard solutions or sample extracts. The vial containing the reaction mixture was capped, vortexed, then incubated at $50^{\circ} \mathrm{C}$ for 50 min under stirring in an SH 2000-DX Thermo mixer (Finepcr, Seoul, Korea). In order to remove the Dns-Cl excess, the mixture was treated with $30 \mu \mathrm{L}$ of $\mathrm{NaOH} 5 \mathrm{M}$,

Table 1. Results from method validation for quantification of the dansylated biogenic amines.

\begin{tabular}{lcccc}
\hline Amines & linearity Range $\left(\mathrm{R}^{2}\right)$ & Recovery $(\% \pm S D)$ & LoD* & LoQ $^{*}$ \\
Tryptamine & $1-250(0.997)$ & $90 \pm 6$ & 0.3 & 1.0 \\
B-Phenylethylamine & $0.6-250(0.998)$ & $92 \pm 5$ & 0.2 & 0.6 \\
\hline Putrescine & $0.2-250(0.999)$ & $97 \pm 3$ & 0.06 & 0.2 \\
Cadaverine & $0.2-250(0.999)$ & $95 \pm 4$ & 0.08 & 0.02 \\
\hline Histamine & $10-250(0.996)$ & $88 \pm 8$ & 1 & 3 \\
Tyramine & $1.2-250(0.998)$ & $96 \pm 3$ & 0.04 & 1.2 \\
\hline Spermidine & $0.2-250(0.999)$ & $94 \pm 5$ & 0.06 & 0.2 \\
Spermine & $0.2-250(0.999)$ & $92 \pm 6$ & 0.06 & 0.2 \\
\hline
\end{tabular}

*Values expressed as mg $100 \mathrm{~g}^{-1}$. then, to remove the excess of carbonate, 30 $\mu \mathrm{L}$ of glacial acetic acid, and $250 \mu \mathrm{L}$ of acetonitrile was added. The solution was filtered through a $0.22 \mu \mathrm{m}$ PVDF syringe filter (Millipore, Bedford, MA, USA) and then 10 $\mu \mathrm{L}$ were injected in high-performance liquid chromatography. FAA and BA were determined through a Varian (Walnut Creek, CA, USA) chromatography system equipped with a ProStar 230 Solvent Delivery System, a ProStar 410 autosampler, and an LC 305 fluorescent detector (Jasco, Hachioji, Japan). The system was controlled by Varian Star Chromatography Workstation software (Version 5.31). The column used was an Alltima $\mathrm{C}_{18}, 150$ x $4.6 \mathrm{~mm}, 2.6 \mu \mathrm{m}$ [Alltech Italia, Sedriano (MI)] fitted with an Alltima $\mathrm{C}_{18}$ guard column, $7.5 \mathrm{~mm}$ x $4.6 \mathrm{~mm}$ x $5 \mu \mathrm{m}$, thermostated at $33^{\circ} \mathrm{C}$. Detection was carried out with the fluorescent detector operating at 340 and $510 \mathrm{~nm}$ as excitation and emission wavelengths, respectively. Chromatographic analysis was conducted following the Minocha \& Long (2004) method, modified as previously described by Manca (2015). Identification of the nitrogenous compounds was performed by comparing the retention times of peaks in the samples with those of standard solutions and by adding the suspected compound to the samples. The target compounds were quantified using the internal standard method. The HPLC-FL method was validated in terms of linearity, recovery percentage, limit of detection (LoD) and limit of quantification (LoQ), calculated from the amount of BAs required to give a signal-to-noise ratio of 3 , and a signal-to-noise ratio of 10 respectively (Table 1).

\section{Statistical analyses}

The minimum, maximum, average and standard deviation were calculated for each parameter. The results were expressed as means of two replications. One-way ANOVA (followed by Tukey's test) was used to compare mean values. Pearson correlation analysis was conducted to determine the relationship between the different 
parameters considered. Statistical significance was declared at $\mathrm{P} \leq 0.01$. Data were also subjected to hierarchical cluster analysis (HCA), a multivariate procedure to detect groupings in the data. The HCA was done by unweighted pair-group average linkage (between groups) using the squared Euclidean distance. All statistical analyses were performed with the software package SPSS 14 (SPSS Inc., Chicago, IL, USA).

\section{Results and Discussion}

The results of physicochemical parameters, composition and total free amino acid content, measured in the 37 samples of Fiore Sardo PDO cheese, are shown in Table 2. The values for $\mathrm{pH}$, moisture and $\mathrm{NaCl}$ were within the range of those found by Pisano (2006) in the same type of cheese after 6-9 months of ripening. In comparison with the data reported by this latter author there was, however, a discrepancy for $a_{w}$ values which Pisano quantified between $0.75 \pm 0.01$ and $0.79 \pm 0.00$, whereas the mean value found in our study was $0.88 \pm 0.04$. Indeed, only one sample, showing a very hard and dry texture showed an $\mathrm{a}_{\mathrm{w}}$ value of 0.78 close to that found by Pisano (2006). The fat percentage in dry matter was always higher than $40 \%$, in accordance with the Technical Specifications (EC, 1996), and protein in dry matter had mean values of around $41 \%$, as observed by Pisano (2006). The degree of proteolysis in Fiore Sardo cheeses was ascertained by measuring the total amount of FAA (calculated as the sum of the individual FAA), with a mean \pm sd of $2233 \pm 764 \mathrm{mg} 100 \mathrm{~g}^{-1}$, close to the value

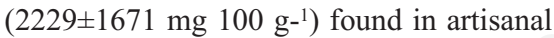
Pecorino made with raw ewe's milk (Manca et al., 2015). The average of this parameter was higher than that found in Fiore Sardo (1259 mg/100ml) by De Pasquale (2016); however, it should be emphasised that the results of this latter author referred to cheeses after 4 months of ripening and obtained from a single producer. The amino acid profile was similar to that found in other artisanal sheep's milk cheeses (Izco et al., 2000; Pappa et al., 2008; Manca et al., 2015; De Pasquale et al., 2016). Glutamic acid, leucine, valine and lysine were the amino acids mostly frequently present. These are the most abundant FAA when lactococci and lactobacilli constitute the dominant microflora, as observed in other raw ewe's milk cheeses (Pintado et al. 2008) as well as in Fiore Sardo (Pisano et al. 2006). Total BA content was $127 \pm 87 \mathrm{mg} 100 \mathrm{~g}^{-1}$ (Table 3), higher than $70 \pm 40 \mathrm{mg} 100 \mathrm{~g}-^{1}$ found in a previous work on Fiore Sardo (Zazzu et al, 2019). As observed in this lat- ter work, which considered cheeses obtained from four producers only, our results, based on products from a greater number of producers, confirmed the large variability in BA content in Fiore Sardo cheese. The use of raw milk with different degrees of hygienic quality and sometimes with uncontrolled temperature and humidity storage conditions, combined with different cheesemaking practices, can affect the conditions promoting the growth and activity of certain groups of microorganisms involved in proteolytic degradation and biogenic amine synthesis (Novella-Rodriguez et al., 2003; Pintado et al., 2008). The level of BA found in this study was similar to that reported by other authors for different types of raw ewe's milk cheeses, such as the Sardinian Pecorino (Manca et al., 2015), Formaggio di Fossa (Mascaro et al., 2010), Pecorino di Farindola (Schirone et al., 2011) and Pecorino Abruzzese (Martuscelli et al., 2005). Tyramine was the main biogenic amine in the samples analysed (Table

3 ), as in the other types of cheese quoted above. Tyramine concentration was $82 \pm 51$ mg $100 \mathrm{~g}-^{-1}$, representing $64 \%$ of the mean total BA content, followed by putrescine (mean value $21 \pm 26 \mathrm{mg} 100 \mathrm{~g}-^{1}$ ). Cadaverine, histamine, $\beta$-phenylethylamine and tryptamine were generally detectable at

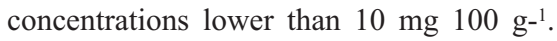
These latter amines were sometime absent; histamine in particular was not detected in around $60 \%$ of the samples considered. Spermidine and spermine were never found, as observed in other types of raw ewe's milk cheese (Martuscelli et al., 2005; Manca et al., 2015). Currently, no legal limit has been established for BA in cheese, but previous studies suggested safety limits for tyramine at $100-800 \mathrm{mg} \mathrm{kg}^{-1}$, for histamine at 50 $100 \mathrm{mg} \mathrm{kg}^{-1}$ (Nout, 1994), and for total BA content at $900 \mathrm{mg} \mathrm{kg}^{-1}$ (Shalaby, 1996).

Considering the lower and upper thresholds suggested for tyramine and histamine, the Fiore Sardo samples that exceeded the proposed limits ranged between $89-46 \%$

Table 2. Physicochemical parameters, composition and total free amino acid content in Fiore Sardo PDO cheese samples.

\begin{tabular}{lcccc} 
Parameters & Mean & SD & Min & Max \\
$\mathrm{a}_{\mathrm{w}}$ & 0.884 & 0.037 & 0.780 & 0.948 \\
$\mathrm{pH}$ & 5.14 & 0.18 & 4.81 & 5.52 \\
\hline *Humidity & 28.70 & 3.79 & 17.41 & 36.20 \\
*Dry matter & 71.30 & 3.79 & 63.8 & 82.59 \\
\hline *Fat & 35.65 & 3.12 & 29.19 & 45.35 \\
*Fat/DM & 50.00 & 3.34 & 42.82 & 55.68 \\
\hline *Protein & 29.26 & 1.90 & 25.78 & 33.08 \\
*Protein/DM & 41.05 & 1.66 & 36.16 & 44.82 \\
\hline *Salt & 3.29 & 0.94 & 1.75 & 5.05 \\
*Salt/DM & 4.62 & 1.31 & 2.52 & 6.88 \\
\hline ** $\Sigma$ FAA & 2233 & 764 & 694 & 4214 \\
** $\Sigma$ FAA/DM & 3146 & 1112 & 933 & 6192 \\
\hline
\end{tabular}

*Values expressed as $\mathrm{g} 100 \mathrm{~g}^{-1}$; **values expressed as mg $100 \mathrm{~g}^{-1}$. DM= dry matter.

Table 3. Biogenic amine content in Fiore Sardo PDO cheeses. Values expressed as $\mathbf{m g} 100 \mathbf{g}^{-1}$.

\begin{tabular}{lcccc} 
Parameters & Mean & SD & Min & Max \\
Tryptamine & 3 & 2 & n.d. & 8 \\
B-Phenylethylamine & 7 & 9 & n.d. & 46 \\
\hline Putrescine & 21 & 26 & n.d. & 95 \\
Cadaverine & 6 & 7 & n.d. & 33 \\
\hline Histamine & 8 & 13 & n.d. & 65 \\
Tyramine & 82 & 51 & 3 & 200 \\
\hline Spermidine & n.d. & n.d. & n.d. & n.d. \\
Spermine & n.d. & n.d. & n.d. & n.d. \\
\hline SBA & 127 & 87 & 6 & 366 \\
$\Sigma$ BA/DM & 179 & 122 & 8 & 501
\end{tabular}

DM= dry matter. 
and $40-24 \%$, respectively. On the basis of the sum of BAs $\left(\Sigma_{\mathrm{BA}}\right)$, and in view of the recommended limit, $56 \%$ of the samples exceeded the limit of $900 \mathrm{mg} \mathrm{kg}^{-1}$ and this could represent a possible risk for consumers. In order to evaluate the possible relationship between $\mathrm{BA}$ content and the variables $\mathrm{a}_{\mathrm{w}}, \mathrm{pH}, \mathrm{NaCl}$ and total FAA content, Pearson's test was used (Table 4). A significant positive correlation between total FAA and total BA content, as well as the single biogenic amines was found. This result confirmed that the availability of free amino acid, ensured by proteolysis, supports the formation of biogenic amines in Fiore Sardo, as highlighted in other types of cheese (Mascaro et al., 2010; Loizzo et al., 2013; Manca et al., 2015). As a consequence of proteolysis, total FAA and BA were positively correlated with $\mathrm{pH}$. This correlation has been observed in other cheeses, such as Terrincho cheese (Pintado et al., 2008) after a short ripening time, where low $\mathrm{pH}$ was correlated with the lowest tyramine concentrations. The biogenic amines analysed were not correlated with $\mathrm{NaCl}$ concentration, with the exception of cadaverine that had a weak positive correlation $(\mathrm{P} \leq 0.05)$ with this variable. A high concentration of $\mathrm{NaCl}$ could inhibit the growth or decarboxylase activity of some species of bacteria (Santos et al., 2003; Linares et al., 2012; Gardini et al., 2016). In Fiore Sardo the salt content did not seem to influence either proteolytic activity or BA formation. Biogenic amines were not correlated with the variables $\mathrm{a}_{\mathrm{w}}$ and humidity. Considering that these latter tend to be related to ripening time, the duration of maturation did not

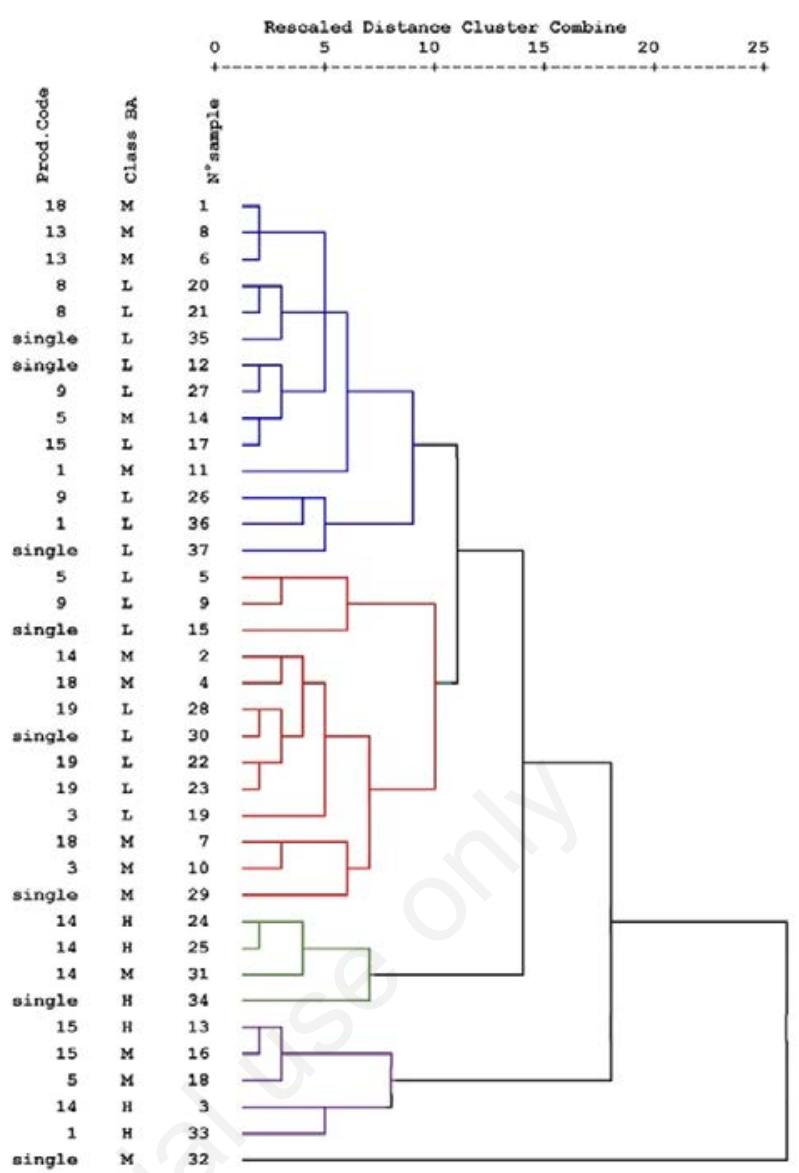

Code producers $=$ samples with the same number were obtained from the same producers. Single $=$ producers that have provider only one sample.

Class $\mathrm{BA}=$ three classes differentiated in accordance with the $\mathrm{BA}$ content: $\mathrm{L}(\Sigma \mathrm{BA} \leq 100), \mathrm{M}(101 \leq \Sigma \mathrm{BA} \geq 200)$ and $\mathrm{H}(\Sigma \mathrm{BA} \geq 200)$.

Figure 1. Dendrogram obtained by Hierarchical cluster analysis using data set of six variables and 37 cheese samples.

Table 4. Pearson correlation coefficients among the physicochemical parameters, total free amino acid and biogenic amine content measured in Fiore Sardo PDO cheeses.

\begin{tabular}{|c|c|c|c|c|c|c|c|c|c|c|c|c|c|c|}
\hline & $a_{w}$ & $\mathrm{pH}$ & Humidity & Fat & Protein & Salt & Dry matter & Tryptamine & $\begin{array}{l}\beta \text {-Phenyl- } \\
\text { ethylamine }\end{array}$ & utresc & adav & ami & Tyramine $\Sigma$ BA & $\Sigma F A A$ \\
\hline$a_{w}$ & 1 & $00.386^{*}$ & $0.697^{* *}$ & -0.070 & $-0.731^{* *}$ & $-0.742 * *$ & $-0.697 * *$ & -0.115 & -0.29 & -0.01 & -0.119 & 0.023 & $\begin{array}{ll}-0.098 & -0.100\end{array}$ & -0.084 \\
\hline $\mathrm{pH}$ & $0.386 *$ & 1 & 0.255 & -0.105 & -0.049 & $-0.499 * *$ & -0.255 & 0.157 & 0.213 & 0.276 & 0.013 & 0.292 & $0.465^{* *} 0.428^{* *}$ & $0.635^{* *}$ \\
\hline Humidity & $0.697 * *$ & 0.255 & 1 & $-0.643^{* *}$ & $-0.776^{* *}$ & -0.165 & $-10.000 * *$ & -0.074 & -0.239 & 0.159 & 0.226 & 0.020 & $\begin{array}{cc}-0.076 & -0.001\end{array}$ & 0.106 \\
\hline Fat & -0.070 & -0.105 & $-0.643^{* *}$ & 1 & 0.089 & $-0.420 * *$ & $0.643^{* *}$ & 0.075 & -0.027 & -0.228 & $-0.471^{* *}$ & 0.235 & -0.055 & -0.288 \\
\hline Protein & $-0.731^{* *}$ & -0.049 & $-0.776 * *$ & 0.089 & 1 & 0.318 & $0.776 * *$ & 0.123 & $0.401^{*}$ & -0.006 & 0.021 & -0.150 & 0.125 & 0.206 \\
\hline Salt & $-0.742 * *$ & $-0.499 * *$ & -0.165 & $-0.420 * *$ & 0.318 & 1 & 0.165 & -0.097 & 0.105 & 0.028 & $0.332 *$ & -0.234 & $\begin{array}{cc}-0.117 & -0.060\end{array}$ & -0.107 \\
\hline Dry matter & $-0.697 * *$ & -0.255 & $-1.000^{* *}$ & $0.643^{* *}$ & $0.776^{* *}$ & 0.165 & 1 & 0.074 & 0.239 & -0.159 & -0.227 & -0.019 & 0.001 & -0.106 \\
\hline Tryptamine & -0.115 & 0.157 & -0.074 & 0.075 & 0.123 & -0.097 & 0.074 & 1 & 0.172 & 0.018 & -0.046 & 0.205 & $0.367^{*} \quad 0.293$ & $0.433 * *$ \\
\hline $\begin{array}{l}\text { B- } \\
\text { Phenylethyla }\end{array}$ & $n e^{-0.290}$ & 0.213 & -0.239 & -0.027 & $0.401^{*}$ & 0.105 & 0.239 & 0.172 & 1 & $639 * *$ & $0.383 *$ & 0.100 & $0.740 * * 0.779 * *$ & $0.359^{*}$ \\
\hline Putrescine & -0.010 & 0.276 & 0.159 & -0.228 & -0.006 & 0.028 & -0.159 & 0.018 & $0.639^{* *}$ & 1 & $0.576^{* *}$ & 0.218 & $0.587^{* *} 0.790 * *$ & $0.412^{*}$ \\
\hline Cadaverine & -0.119 & 0.013 & 0.226 & $-0.471^{* *}$ & 0.021 & $0.332 *$ & -0.227 & -0.046 & $0.383^{*}$ & $576^{* *}$ & 1 & -0.098 & $0.262 \quad 0.433^{* *}$ & 0.142 \\
\hline Histamine & 0.023 & 0.292 & 0.020 & 0.235 & -0.15 & -0.234 & -0.019 & 0.205 & 0.100 & 0.218 & -0.098 & 1 & $0.519^{* *} 0.532 * *$ & $0.429 * *$ \\
\hline Tyramine & -0.098 & $0.465^{* *}$ & -0.076 & 0.030 & 0.176 & -0.117 & 0.076 & $0.367^{*}$ & $0.740^{* *}$ & $587 * *$ & 0.262 & $0.519^{* *}$ & $0.951^{* *}$ & $0.596 * *$ \\
\hline$\sum \mathrm{BA}$ & -0.100 & $0.428 * *$ & -0.001 & -0.055 & 0.125 & -0.060 & 0.001 & 0.293 & $0.779^{* *}$ & $790 * *$ & $0.433^{* *}$ & $0.532 * *$ & $0.951^{* *}$ & $0.599 * *$ \\
\hline$\Sigma \mathrm{FAA}$ & -0.084 & $0.635 * *$ & 0.106 & -0.288 & 0.206 & -0.107 & -0.106 & $0.433^{* *}$ & $0.359 *$ & $0.412^{*}$ & 0.142 & $0.429^{* *}$ & $0.596 * * 0.599 * *$ & 1 \\
\hline
\end{tabular}

BA, biogenic amines; FAA free amino acids. ${ }^{*}$ Correlation is significant at the $\mathrm{P}<0.01$. ${ }^{*}$ Correlation is significant at the $\mathrm{P}<0.05$. 
seem to be one of the main factors affecting biogenic amine formation in Fiore Sardo, as highlighted in other raw ewe's milk cheese (Manca et al 2015). Given the variability of the parameters measured, hierarchical cluster analysis (HCA) was performed to identify similarities and correlations between the samples of cheeses, using 37 objects and 6 variables $\left(\mathrm{a}_{\mathrm{w}}\right.$, humidity, $\mathrm{pH}$ and the content in dry matter of $\mathrm{NaCl}$, total FAA and total BA). The hierarchical clustering results can be seen in Figure 1. To get a clearer view of the dendrogram, the samples were divided into three classes, according to their total BA content: $\mathrm{L}\left(\Sigma_{\mathrm{BA}} \leq 90 \mathrm{mg} 100\right.$ $\left.\mathrm{g}^{-1}\right), \mathrm{M}\left(91 \leq \Sigma_{\mathrm{BA}} \geq 200 \mathrm{mg} 100 \mathrm{~g}^{1}\right)$ and $\mathrm{H}$ $\left(\Sigma_{\mathrm{BA}} \geq 200 \mathrm{mg} 100 \mathrm{~g}^{-1}\right)$. In the dendrogram four groups of cheeses and one outlier (sample $\mathrm{N}^{\circ} 32$ that presented the lowest $\mathrm{a}_{\mathrm{w}}$ value recorded) were identified. The samples with $\Sigma_{\mathrm{BA}} \geq 200 \mathrm{mg} 100 \mathrm{~g}{ }^{-1}$ were distributed in two groups $\left(\mathrm{N}^{\circ} \mathrm{s} 3\right.$ and 4$)$ and those with $\Sigma_{\mathrm{BA}} \leq 90$ and $91 \leq \Sigma_{\mathrm{BA}} \geq 200 \mathrm{mg} 100 \mathrm{~g}-^{1}$ in the other two ( $\mathrm{N}^{\circ} \mathrm{s} 1$ and 2). To highlight the differences between the groups identified by HCA, in Table 5 the mean, standard deviation and Tukey's test results of the parameters measured were shown. Higher $\mathrm{pH}$ levels were found in the samples belonging to group $\mathrm{N}^{\circ} 3$ and, to a lesser extent, to those of group $\mathrm{N}^{\circ} 4$ (mean values $5.4 \div 0.1$ and $5.2 \div 0.1$, respectively), confirming that this variable was clearly related to proteolysis and BA formation. The samples of groups $\mathrm{N}^{\circ} 2$ and 4 presented a higher level of $\mathrm{NaCl}(4.23 \div 0.73$ and $3.64 \div 0.67$ mg 100 g- $^{1}$, respectively) but significant differences in total BA content $(111 \pm 42$ and $279 \pm 73 \mathrm{mg} 100 \mathrm{~g}-^{1}$, respectively) and FAA $(2360 \pm 629$ and $2960 \pm 161 \mathrm{mg} 100 \mathrm{~g}-1$, respectively). Groups $\mathrm{N}^{\circ} 3$ and 4 also showed the highest levels of the single amines, with the exception of histamine content that was higher in group 3, characterised by significant higher levels of $\mathrm{pH}$ and humidity and a lower content of $\mathrm{NaCl}$. HCA highlighted that Fiore Sardo PDO is marketed with rather different compositional characteristics that could influence its organoleptic and wholesome quality. The variability observed for the parameters measured may be due to differences in milk composition and/or manufacturing processes (Pisano et al., 2006). In fact, the Technical Specifications allow the use of various technological options: different type of rennet (lamb or goat), addition or not of starters, different duration of ripening and related conditions (e.g. temperature), factors that are able to influence the characteristics of the cheese (Vicente et al 2001; Pisano et al. 2007; Pappa et al., 2008; Doeum et al., 2017). In addition, by means of HCA it was possible to assess how the manufacturing processes differ from one producer to another; however, they seem quite constant for the single producers over time. In fact, as shown in Figure 1, almost all the samples from the same producer were included in the same group.

\section{Conclusions}

Great variability was observed for $\mathrm{a}_{\mathrm{w}}$, $\mathrm{pH}$, humidity and $\mathrm{NaCl}$ concentration as well as for total free amino acid and biogenic amine content. Considering the total BA content, $54 \%$ of the samples exceeded the threshold of $90 \mathrm{mg} 100 \mathrm{~g}^{-1}$ and could represent a possible risk for consumers. As observed in other types of raw sheep's milk cheese, tyramine was the most frequently present amine, followed by putrescine (64\% and $16 \%$ of the total BA content, respectively). The Pearson correlation test highlighted a positive correlation between the total content of BA and that of FAA. In Fiore Sardo both ripening time and proteolysis activity promote the availability of amino acid precursors that are fundamental for the formation of BA. The content of these nitroge- nous compounds was consistently related with a higher $\mathrm{pH}$, and it was also affected by proteolytic activity. $\mathrm{A}_{\mathrm{w}}$, humidity and $\mathrm{NaCl}$ content were not related to BA, indicating that they did not represent a risk-limiting factor. These results were confirmed by the HCA, which clustered the samples with the highest level of biogenic amines in two groups with high levels of $\mathrm{pH}$ in common, but significant different levels of $\mathrm{a}_{\mathrm{w}}$, humidity and salt. In addition, HCA showed that samples from the same producer were usually placed in the same group for BA levels, giving evidence of repeatability of the processes. A comparison between the process conditions used by the groups of producers identified could give indications to pick out factors affecting BA content. In fact, due to the role of autochthonous bacteria in determining the organoleptic and qualitative characteristics of Fiore Sardo PDO cheese, it is difficult to suggest interventions involving the microbiota to reduce the risks related to BA. More appropriate combinations of other technological factors

\section{References}

De Pasquale I, Di Cagno R, Buchin S, De

Table 5. Mean and standard deviation of the physicochemical parameters, total free amino acid and biogenic amine content of the four groups identified by means of hierarchical cluster analysis (HCA).

\begin{tabular}{|c|c|c|c|c|}
\hline \multirow[t]{2}{*}{ Parameters } & \multicolumn{4}{|c|}{ Group } \\
\hline & 1 & 2 & 3 & 4 \\
\hline$a_{w}$ & $0,90 \pm 0,03^{\mathrm{b}}$ & $0,86 \pm 0,02^{\mathrm{a}}$ & $0,92 \pm 0,01^{\mathrm{b}}$ & $0,85 \pm 0,01^{\mathrm{a}}$ \\
\hline $\mathrm{pH}$ & $5,1 \pm 0,2^{\mathrm{a}}$ & $5,1 \pm 0,1^{\mathrm{a}}$ & $5,4 \pm 0,1^{\mathrm{b}}$ & $5,2 \pm 0,1^{\mathrm{ab}}$ \\
\hline *Humidity & $28,7 \pm 3,6^{\mathrm{ab}}$ & $29,7 \pm 2,7$ ab & $31,3 \pm 1,1^{\mathrm{b}}$ & $25,3 \pm 3,0^{\mathrm{a}}$ \\
\hline *Dry matter & $71,3 \pm 3,6^{\text {ab }}$ & $70,3 \pm 2,7 \mathrm{ab}$ & $68,7 \pm 1,1^{\mathrm{a}}$ & $74,7 \pm 3,0^{\mathrm{b}}$ \\
\hline *Fat & $36,7 \pm 2,1^{\text {ab }}$ & $33,2 \pm 2,7^{\mathrm{a}}$ & $36,0 \pm 0,6^{\mathrm{ab}}$ & $35,5 \pm 3,4^{\mathrm{ab}}$ \\
\hline *Fat/DM & $51,5 \pm 2,0^{\mathrm{b}}$ & $47,2 \pm 3,4^{\mathrm{a}}$ & $52,4 \pm 1,4^{b}$ & $47,4 \pm 2,6^{\mathrm{a}}$ \\
\hline *Protein & $28,8 \pm 1,7^{\mathrm{a}}$ & $29,2 \pm 1,8^{\mathrm{a}}$ & $28,1 \pm 1,2^{\mathrm{a}}$ & $31,9 \pm 0,9^{b}$ \\
\hline *Protein/DM & $40,5 \pm 1,4^{\mathrm{a}}$ & $41,7 \pm 1,8^{\mathrm{ab}}$ & $40,8 \pm 1,1^{\mathrm{ab}}$ & $42,8 \pm 0,9^{b}$ \\
\hline *Salt & $2,90 \pm 0,60^{\mathrm{ab}}$ & $4,23 \pm 0,73^{c}$ & $2,15 \pm 0,42^{\mathrm{a}}$ & $3,64 \pm 0,67^{\text {bc }}$ \\
\hline *Salt/DM & $4,07 \pm 0,81^{\mathrm{ab}}$ & $6,01 \pm 0,97^{c}$ & $3,14 \pm 0,65^{\mathrm{a}}$ & $4,91 \pm 1,04^{\mathrm{bc}}$ \\
\hline$* * \sum$ FAA & $1725 \pm 523^{a}$ & $2360 \pm 629^{a b}$ & $3133 \pm 165^{b}$ & $2960 \pm 161^{\mathrm{b}}$ \\
\hline$* * \Sigma$ FAA/DM & $2421 \pm 729^{\mathrm{a}}$ & $3368 \pm 926^{\mathrm{ab}}$ & $4566 \pm 1051^{\mathrm{b}}$ & $3969 \pm 259^{\mathrm{b}}$ \\
\hline$* * \Sigma \mathrm{BA}$ & $71 \pm 43^{a}$ & $111 \pm 42^{\mathrm{a}}$ & $223 \pm 69^{b}$ & $279 \pm 73^{b}$ \\
\hline$* * \Sigma \mathrm{BA} / \mathrm{DM}$ & $100 \pm 60^{\mathrm{a}}$ & $158 \pm 61^{\mathrm{a}}$ & $325 \pm 105^{b}$ & $375 \pm 104^{b}$ \\
\hline **Tryptamine & $2 \pm 1^{\mathrm{a}}$ & $3 \pm 3^{\mathrm{a}}$ & $4 \pm 3^{a}$ & $4 \pm 2^{a}$ \\
\hline${ }^{* *} \beta$-Phenylethylamine & $4 \pm 3^{\mathrm{a}}$ & $4 \pm 2^{a}$ & $9 \pm 4^{\mathrm{a}}$ & $26 \pm 17^{\mathrm{b}}$ \\
\hline **Putrescine & $9 \pm 14^{\mathrm{a}}$ & $19 \pm 19$ ab & $45 \pm 21^{\text {bc }}$ & $53 \pm 43^{c}$ \\
\hline${ }^{* *}$ Cadaverine & $3 \pm 3^{\mathrm{a}}$ & $9 \pm 9^{\mathrm{ab}}$ & $6 \pm 8^{\mathrm{ab}}$ & $14 \pm 9^{b}$ \\
\hline **Histamine & $3 \pm 4^{a}$ & $7 \pm 9^{\mathrm{a}}$ & $25 \pm 27^{c}$ & $11 \pm 13^{b c}$ \\
\hline **Tyramine & $51 \pm 33^{a}$ & $69 \pm 26^{\mathrm{a}}$ & $136 \pm 33^{b}$ & $171 \pm 37^{b}$ \\
\hline
\end{tabular}

*Values expressed as $\mathrm{g} 100 \mathrm{~g}^{-1}$. **Values expressed as $\mathrm{mg} 100 \mathrm{~g}^{-1}$. DM= dry matter. a,b,Tukey's test results, mean values within columns with a different letter are significantly different $(\mathrm{P} \leq 0.05)$. 
Angelis M, Gobbetti M, 2016. Spatial distribution of the metabolically active microbiota within Italian PDO Ewes' Milk Cheeses. PLoS ONE 11:1-23.

Doeun D, Davaatseren M, Chung MS, 2017. Biogenic amines in foods. Food Sci Biotechnol 26:1463-74.

European Commission, 1996. Commission Regulation (EC) No 1263/96 of 1 July 1996 supplementing the Annex to Regulation (EC) No 1107/96 on the registration of geographical indications and designations of origin under the procedure laid down in Article 17 of Regulation (EEC) No 2081/92. In: Official Journal, L 163/19, 2/07/1996.

Eerola S, Hinnkkainnen R, Lindfors E, Hirvi T, 1993. Liquid chromatographic determination of biogenic amines in dry sausages. J AOAC Int 76:575-7.

European Food Safety Authority (EFSA panel on biological hazards), 2011. Scientific opinion on risk based control of biogenic amine formation in fermented foods. EFSA J 9:1-93.

Gardini F, Özogul Y, Suzzi G, Tabanelli G, Özogul F, 2016. Technological factors affecting biogenic amine content in foods: A Review. Front Microbiol 7:1218.

Izco JM, Torre P, Barcina Y, 2000. Ripening of Ossau-Iraty cheese: determination of free amino acids by RP-HPLC and of total free amino acids by the TNBS method. Food Control 11:7-11.

Kim MK, Mah JH, Hwang HJ, 2009. Biogenic amine formation and bacterial contribution in fish, squid and shellfish. Food Chem 116:87-95.

Ladero V, Calles-Enríquez M, Fernández M, Álvarez MA, 2010. Toxicological effects of dietary biogenic amines. Curr Nutr Food Sci 6:145-56.

Linares DM, Del Río B, Ladero V, Martínez N, Fernández M, Martín MC, Alvarez MA, 2012. Factors influencing biogenic amines accumulation in dairy products. Front Microbiol 3:1-10.

Loizzo MR, Menichini F, Picci N, Puoci F, Spizzirri UG, Restuccia D, 2013. Technological aspects and analytical determination of biogenic amines in cheese. Trends Food Sci Tech 30:38-55. Manca G, Porcu A, Ru A, Salaris M, Franco
MA, De Santis EPL, 2015. Comparison of $\gamma$-aminobutyric acid and biogenic amine content of different types of ewe's milk cheese produced in Sardinia, Italy. Ital J Food Saf 4:4700.

Mannu L, Comunian R, Scintu MF, 2000. Mesophilic lactobacilli in Fiore Sardo cheese: PCR-identification and evolution during cheese ripening. Int Dairy J 10:383-9.

Martuscelli M, Gardini F, Torriani S, Mastrocola D, Serio A, Chaves-Lòpez C, Schirone M, Suzzi G, 2005. Production of biogenic amines during the ripening of Pecorino Abruzzese cheese. Int Dairy J 15:571-8.

Mascaro N, Stocchi R, Ricciutelli M, Cammertoni N, Renzi F, Cecchini S, Loschi AR, Rea S, 2010. Biogenic amine content and chemical and physical features of Italian formaggio di Fossa. Ital J Food Saf 8:49-53.

Minocha R, Long S, 2004. Simultaneous separation and quantitation of amino acids and polyamines of forest tree tissues and cell cultures within a single high-performance liquid chromatography run using dansyl derivatization. J Chromatogr A 1035:63-73.

Nout, MJR, 1994. Fermented foods and food safety. Food Res Int 27:291-8.

Novella-Rodríguez S, Veciana-Nogués MT, Izquerdo-Pulido M, Vidal-Carou MC, 2003. Distribution of biogenic amines and polyamines in cheese. J Food Sci 68:750-5.

Pappa EC, Sotirakoglou K, 2008. Changes of free amino acid content of Teleme cheese made with different types of milk and culture. Food Chem 111:60615.

Pintado AIE, Pinho O, Ferreira IMPLVO, Pintado MME, Gomes AMP, Malcata FX, 2008. Microbiological, biochemical and biogenic amine profiles of Terrincho cheese manufactured in several dairy farms. Int Dairy J 18:631-40.

Pisano MB, Fadda ME, Deplano M, Corda A, Cosentino S, 2006. Microbiological and chemical characterization of Fiore Sardo, a traditional Sardinian cheese made from ewe's milk. Int J Dairy Tech 59:171-9.

Pisano MB, Fadda ME, Deplano M, Corda
A, Casula M, Cosentino S, 2007. Characterization of Fiore Sardo cheese manufactured with the addition of autochthonous cultures. J Dairy Res 74:255-61.

Premont RT, Gainetdinov RR, Caron MG, 2001. Following the trace of elusive amines. Proc Natl Acad Sci USA 98:9474-5.

Santos WC, Souza MR, Cerqueira MMOP, Gloria, MBA, 2003. Bioactive amines formation in milk by Lactococcus in the presence or not of rennet and $\mathrm{NaCl}$ at 20 and $32^{\circ} \mathrm{C}$. Food Chem 81:595-606.

Schirone M, Tofalo R, Mazzone G, Corsetti A, Suzzi G, 2011. Biogenic amine content and microbiological profile of Pecorino di Farindola cheese. Food Microbiol 28:128-36.

Schirone M, Tofalo R, Visciano P, Corsetti A, Suzzi G, 2012. Biogenic amines in Italian Pecorino cheese. Front Microbiol 3:171.

Shalaby AR, 1996. Significance of biogenic amines to food safety and human health. Food Res Int 29:675-90.

Silla Santos MH, 1996. Biogenic amines: their importance in food. Int $\mathrm{J}$ Food Microbiol 29:213-31.

Smith TA, 1981. Amines in food. Food Chem 6:169-200.

Taylor SL, 1986. Histamine food poisoning: toxicology and clinical aspects. CRC Crit. Rev. Toxicol 17:91-128.

Ten Brink B, Damink C, Joosten HMLJ, Veld Huis JHJ, 1990. Occurrence and formation of biologically active amines in foods. Int J Food Microbiol 11:73-84.

Vicente MS, Ibanez FC, Barcina Y, Barron LJR, 2001. Changes in the free amino acid content during ripening of Idiazabal cheese: Influence of starter and rennet type. Food Chem 72:309-17.

Zazzu C, Addis M, Caredda M, Scintu MF, Piredda G, Sanna G, 2019. Biogenic Amines in Traditional Fiore Sardo PDO Sheep Cheese: Assessment, Validation and Application of an RP-HPLC-DADUV Method. Separations 6:11. 